\title{
Tax Sovereignty and Investor Protection: Why the Proposed Global Minimum Tax Is not the Final Frontier for Corporate Tax Arbitrage ${ }^{1}$
}

\author{
M.F. Motala
}

Michael F. Motala - Teaching Fellow International Economic Law, Business and Policy (IELBP) and Lecturer in Law, Stanford Law School; Crown Quadrangle 336, 559 Nathan Abbott Way, Stanford, California, USA, 94305; E-mail: motala@law.stanford.edu

\begin{abstract}
Over the past decade, international tax governance has evolved with bewildering speed in response to the challenges of digitalization and widespread corporate tax avoidance. Since the launch of the Group of 20(G20)-Organisation for Economic Co-operation and Development (OECD) base erosion and profit shifting (BEPS) initiative in 2012, 135 countries and 14 international organizations have joined the BEPS Inclusive Framework, committing to implement new global standards on corporate tax, which has already been lauded as a revolution in the architecture of international tax law and policy. Even further expanding the scope of the OECD's work on international taxation in a landmark announcement in March 2021, the U.S. administration further proposed imposing a global minimum corporate tax at a rate of $21 \%$ to be implemented through an international agreement by mid-2021. If the new OECD initiative is agreed, will the plan to implement a minimum corporate tax be fully implemented by $G 20$ members, and if so, will it do enough to address the tax challenges of digitalization embodied in corporate tax arbitrage? Although the evidence suggests legislative and public policy compliance is likely to be high among G20 members, this article argues the minimum tax initiative is unlikely to go far enough to address deficiencies in global tax dispute resolution, which are extremely germane to the success of the proposed minimum tax. As explained in this article, U.S. leaders and global policymakers must enhance the mutual agreement procedure (MAP), a cornerstone of tax dispute resolution, given a growing body of tax litigation in investment law that threatens the implementation of BEPS 2.0. To do so, global policymakers must also reconcile the conflict of norms between tax sovereignty and investor protection contained in the investor-state dispute settlement (ISDS) regime. Only by addressing the conflict between the principles of tax sovereignty and investor protection can they prevent a tidal wave of investor disputes that will challenge the implementation of the minimum tax through national tax laws.
\end{abstract}

Key words: global minimum tax; tax challenges of digitalization; Group of 20 (G20); Organisation for Economic Co-operation and Development (OECD); international taxation; global governance; international political economy

For citation: Motala M. (2021). Tax Sovereignty and Investor Protection: Why the Proposed Global Minimum Tax Is not the Final Frontier for Corporate Tax Arbitrage. International Organisations Research Journal, vol. 16, no. 2, pp. 99-131 (in English). DOI: 10.17323/1996-7845-2021-02-06

\section{Introduction}

The ongoing digitalization of the global economy since the Great Recession in 2008 has had profound implications for markets, global policy and our everyday lives. New multisided markets for information, goods and services, and capital have emerged, challenged and transformed

${ }^{1}$ The editorial board received the article in May 2021. 
traditional business models with bewildering speed. Built by technology giants such as Alphabet Inc., Amazon Inc. and Facebook, platforms have gradually redistributed market share away from their traditional rivals in newspaper advertising, urban short-distance transport, and brick-and-mortar retail, casting a spotlight on broader commercial trends and international financial flows. Following the emergence of the global COVID-19 pandemic in December 2019, the combination of global lockdowns and the resulting suppression of demand has accelerated the digitalization of the economy, producing uneven gains and losses for participants in their respective sectors.

The digitalization of the economy has had equally profound implications for global financial flows and in particular the corporate tax practices of digital multinationals. In April 2020, Amazon Inc. reported revenues of $\$ 88.9$ billion in the second quarter of 2020 despite lockdown restrictions [Lee, 2020]. Indeed, in 2020, American consumers spent $\$ 861.12$ billion on e-online retail, a 44.0\% increase over the same period in 2019 [Ali, 2021]. That jump in sales corresponded with a growth in the market share of e-commerce, which increased from $15.8 \%$ of total retail sales in 2019 to $21.3 \%$ in 2020 [Ibid.]. Yet the biggest digital multinationals pay relatively little tax. Experts estimate an average of $40 \%$ of multinational corporate profits are offshored to tax havens [Tørsløv, Wier, Zucman, 2018], which totals over \$7.5 trillion dollars of corporate money [Kerzner, Chodikoff, 2016, p. 1]. In its conservative 2015 assessment, the Organisation for Economic Co-operation and Development (OECD) estimated that corporate tax base erosion takes at least $\$ 240$ billion a year from the global tax base, while tax scholars and experts contend it could be $\$ 500$ billion per year or more [OECD, 2015].

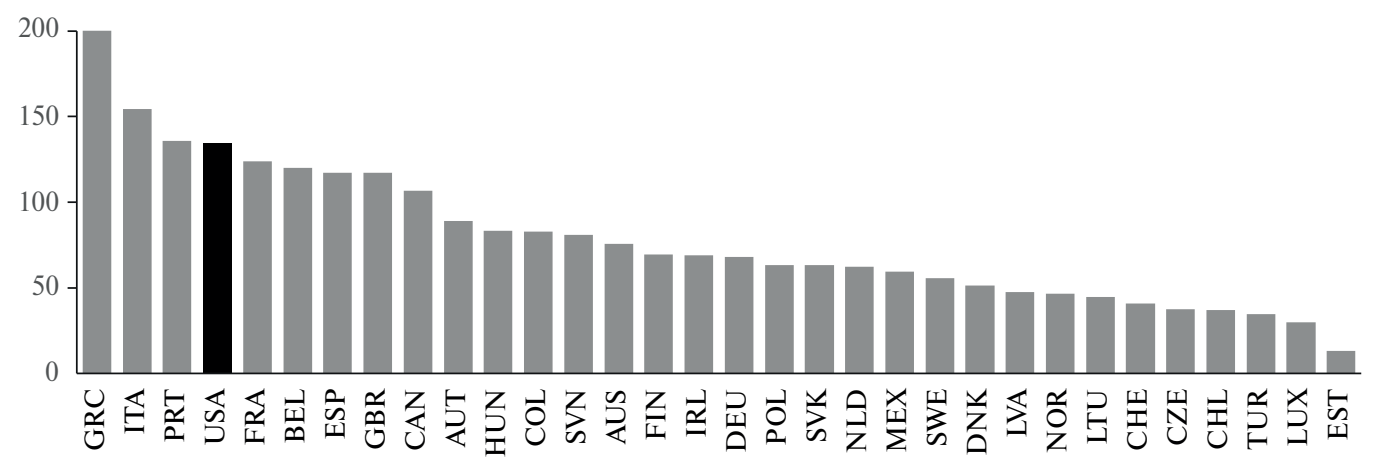

Fig. 1. Debt as Percentage of Gross Domestic Product (GDP) in the OECD Club (2019), \%

Source: [Organisation of Economic Co-Operation and Development, 2021. Data on file with author and available upon request].

Widespread corporate tax base erosion and a new tax-and-spend economic orthodoxy portend a fiscal reckoning in the world's advanced economies. Debt-to-gross domestic product (GDP) ratios have skyrocketed since the first quarter of 2020, with the advanced economies adding \$17 trillion to their government liabilities since the coronavirus crisis began, increasing public debt from an average of $109 \%$ of GDP to $137 \%$ in 2020 [Giles, Harding, 2020]. Advanced economies such as the United Kingdom (UK) are already planning to raise corporate taxation to help find 30 billion pounds to fill a fiscal gap, suggesting similar policies among G20 members [Reuters, 2020]. As depicted above (Fig. 1), Greece, Italy, Portugal, the United States (indicated in light grey) and France had among the top five debt-to-GDP ratios in the OECD in 2019. The foregoing circumstances underscore the need for a more robust global effort to generate additional tax revenues to finance existing debt and new spending. 
The tax policy challenges raised by the new digital economy are far reaching, transcend disciplinary fault lines and occur at all levels of governance. Fortunately, the global governance of corporate taxation from 2008 to 2021 is seen as a successful example of international cooperation, although its institutional evolution has not unfolded smoothly or in a linear fashion. The Group of 20 (G20), which is an informal forum for the world's most powerful countries accounting for approximately $85 \%$ of global GDP, addressed the OECD's analytical work on international taxation at its first summit in Washington in November 2008. In May 2009, President Barack Obama announced that the United States would seek to eliminate corporate tax loopholes, which reflected, a position which reflected the United States' mounting loss of overall tax and corporate tax receipts as a percentage of GDP compared to the OECD club.

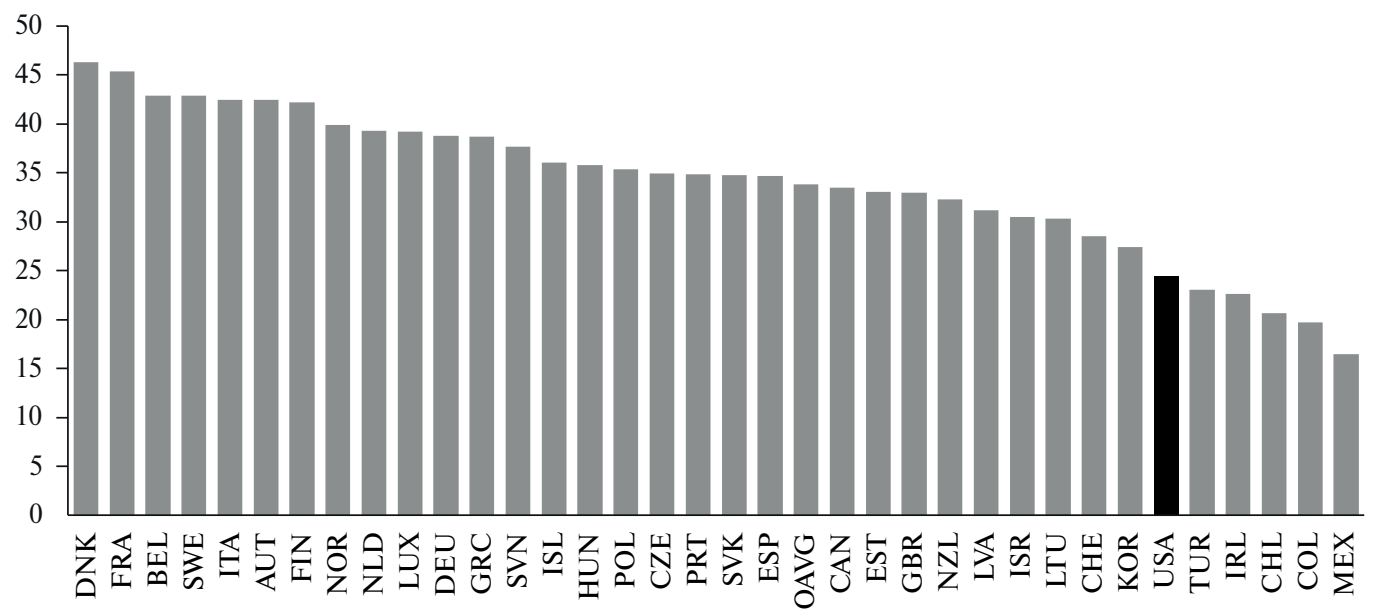

Fig. 2. Overall Tax Receipts as a Percentage of Gross Domestic Product (2019), \%

Source: [Organisation of Economic Co-Operation and Development, 2021. Data on file with author and available upon request].

In December 2012, G20 finance ministers formally tasked the OECD with addressing global tax base erosion and profit shifting (BEPS). Their decision came none too soon. Four months later, over 100 journalists in 60 countries affiliated with the International Consortium of Investigative Journalists (ICIJ) reviewed 2.5 million confidential records about the offshore assets of 170 people and leaked information about more than 130,000 offshore accounts. In June 2013, the OECD delivered its 15-point action plan to the United States government and the G20. It was subsequently endorsed by G20 leaders, who committed to a new Automatic Exchange of Information Standard (AEOI) to address the risks from secretive tax havens. After the G20's Antalya summit, the final BEPS package was agreed, and the focus of global cooperation turned to implementation in national legislative and policy frameworks.

By March 2021, the Inclusive Framework on BEPS boasted a membership of 135 countries and 14 observer organizations such as the International Monetary Fund (IMF), the World Bank (WB), and the United Nations (UN). Member countries must commit to the comprehensive BEPS package, consisting of its 15 action items, and consistently implement new norms, standards and procedures. Participation by all members occurs on an equal footing. To implement Action 15 of the BEPS Framework on dispute resolution, an ad hoc group of countries and observers was formed on 27 May 2015, to draft a multilateral agreement for tax and the Multilateral Instrument (MLI), which has now been signed by 85 countries. It is viewed as the most radical transformation of the international legal framework in over a century. 
The presidency of Donald J. Trump cause an abrupt turn from multilateralism to unilateralism in U.S. foreign tax policy from 2016 to 2020. The U.S. Tax Cuts and Jobs Act (TCJA), signed into law by President Donald J. Trump on 22 December 2017, enacted a $10.5 \%$ minimum global tax on intangible income to discourage profit shifting by transnational corporations (TNCs). This U.S. action was emulated by India, Italy, Spain and the UK. The European Commission (EC) released proposals for taxing TNCs based on the separate concepts of a "digital permanent establishment" or a digital services tax (DST). The Trump administration later rejected a proposed minimum tax standard, which had been agreed in principle by 129 countries in January 2019, insisting on a "safe harbour" mechanism that would allow American technology companies to refrain from paying a minimum corporate tax for their subsidiaries abroad.

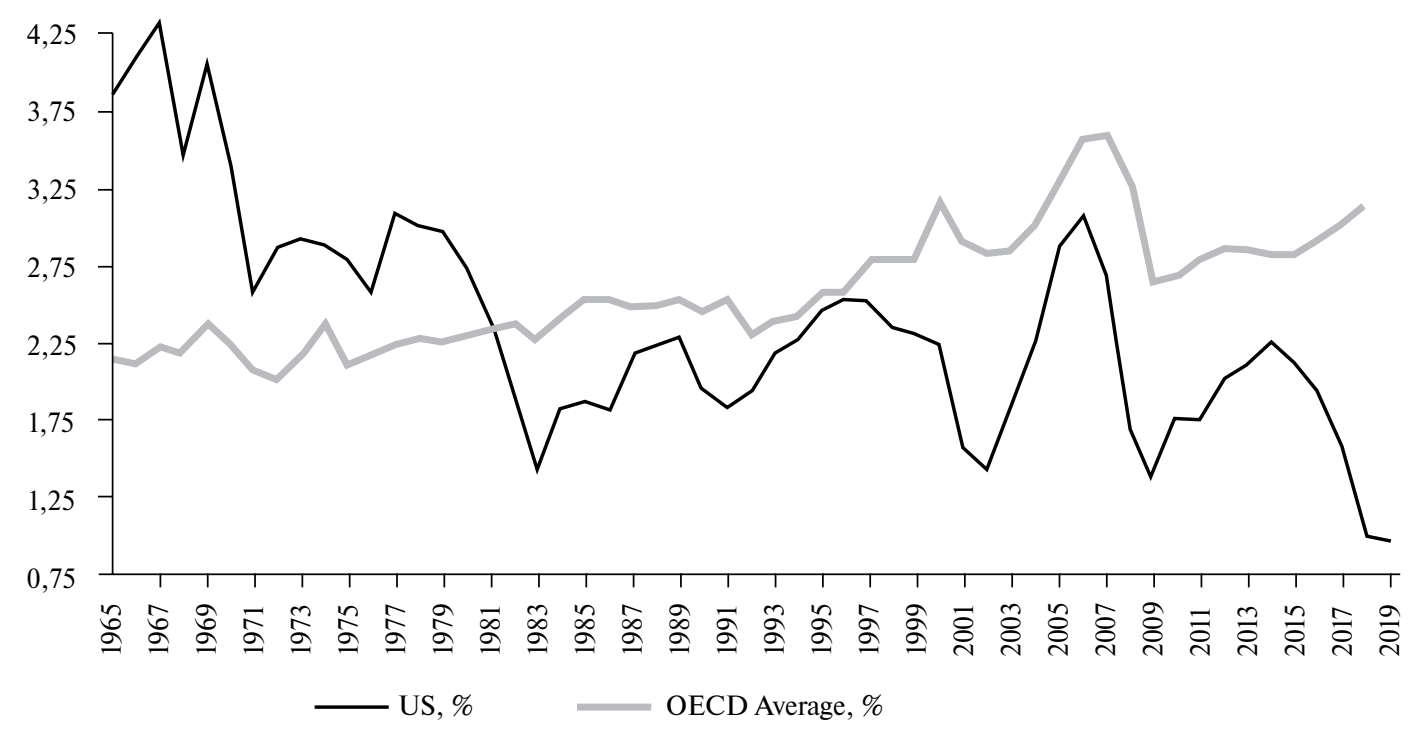

Fig. 3. United States and OECD Average Corporate Tax Receipts as a Percentage of GDP (1965-2019)

Source: Organisation of Economic Co-Operation and Development, 2021. Data on file with author and available upon request.

The inauguration of President Joe Biden brought another tax policy pivot and a renewed focus on addressing America's diminishing share of the global corporate tax pie, as shown below (Fig. 3). On 31 March 2021, President Biden announced his American Jobs Plan, a landmark $\$ 2$ trillion infrastructure proposal to generate jobs, economic growth and competitiveness. Citing a 2019 independent study that found that 91 of the Fortune 500 companies exploited loopholes to avoid paying their fair share of corporate tax, the President proposed a corporate tax increase to $28 \%$ and a $21 \%$ minimum tax on U.S. firms operating abroad, on a country-bycountry basis, to fund his ambitious plan. He also invited 135 countries to take a similar approach and tax corporations in the jurisdiction where the underlying economic activity took place, rather than where the profit was shifted to. The G20 endorsed the proposed minimum digital tax and promised to pursue an international agreement by the summer of 2021. If fully implemented, this would redistribute tax receipts away from tax havens to the countries where business actually takes place. Therefore, this article investigates the following question: assuming this landmark agreement on a global minimum tax is agreed in mid-2021, will G20 members fully implement it, and if so, will their implementation go far enough to address the tax challenges of digitalization embodied in corporate tax arbitrage? 


\section{Thesis}

To answer this question, this article analyzes the prospects for the implementation of a global minimum tax rate among G20 members based on their past compliance with G20 summit taxrelated commitments and its causes, as well as on international relations theory and a thought experiment that involves normative and doctrinal legal analysis from law and economics to address tax enforcement and jurisprudence.

This article argues that G20 compliance with a prospective global minimum corporate tax rate of $21 \%$ will be high, based on their past performance and the distribution of relative capabilities in the international system, but that it will not go far enough. Recent reforms to the global tax dispute resolution mechanisms of the MLI failed to address the substantive deficiencies in the current mutual agreement procedure (MAP), which is the cornerstone of state-to-state tax dispute resolution. In particular, the MAP remains deficient given the lack of binding arbitration, the lack of formal taxpayer standing in the legal process, the bureaucratic inefficiency of the intergovernmental procedure itself, evidence of backlogged cases, and, most critically, the ability for multinational corporations to challenge the implementation of BEPS and a digital tax given loopholes in the related regime of international investment law. Therefore, to advance a new paradigm of tax governance, policymakers should consider more than adding mandatory arbitration to the current MAP. There is in fact a growing number of tax cases in which private corporations challenge the tax laws of sovereign states, indicating a conflict of norms between the international tax and investment regimes that has practical implications for the implementation of a global minimum tax and other BEPS objectives. Put simply, U.S. leaders and global policymakers must address the conflict of norms between tax sovereignty and investor protection and the interaction of tax law with the investor-state dispute settlement (ISDS) regime if BEPS 2.0 is to work.

\section{G20 Performance on International Tax Governance}

To critically assess the prospects for the implementation of a minimum tax, this article first examines past performance in the G20 club. From 2008-18, G20 leaders dedicated 13,146 words to international tax in their summit outcome documents, which represents approximately $7 \%$ of the total. Between the 2008 Washington summit and the 2015 Antalya summit, the number of words per summit ranged from $1 \%$ to $5 \%$. Then it rose at Hangzhou in 2016 to $19 \%$, followed by 14\% at Hamburg in 2017 and 17\% at Buenos Aires in 2018. At Osaka in 2019, it dropped to the level of previous years, 3\%. The chart below (Fig. 4) depicts these trends in conclusions as well as in commitments and compliance.

These conclusions contained 131 collective, politically binding, future-oriented tax commitments, or approximately $5 \%$ of the total on all subjects. The tax commitments averaged approximately eight at each summit since 2008. They ranged from a low of one (or $1 \%$ of the total) in Toronto in June 2010 to a high of 25 (9\%) at St Petersburg in 2013. G20 members' compliance with these summit tax commitments, based on the 31 assessed, averaged $79 \%$, which is substantially higher than the all-subject average of $71 \%$ as shown below (Fig. 5). Their tax compliance was highest from the Toronto summit in 2010 at $98 \%$, where leaders committed to designing and implementing a structure for resolving financial crises without burdening taxpayers. Coming next were Hamburg in 2017, with 97\%, and Antalya in 2015, with 92\%. The lowest compliance was from the 2009 London summit, at which leaders pledged to take countermeasures against non-cooperative tax jurisdictions, with 53\%. Also low was Cannes in 2011, with 54\%. In the middle was St Petersburg in 2013, with $71 \%$. 


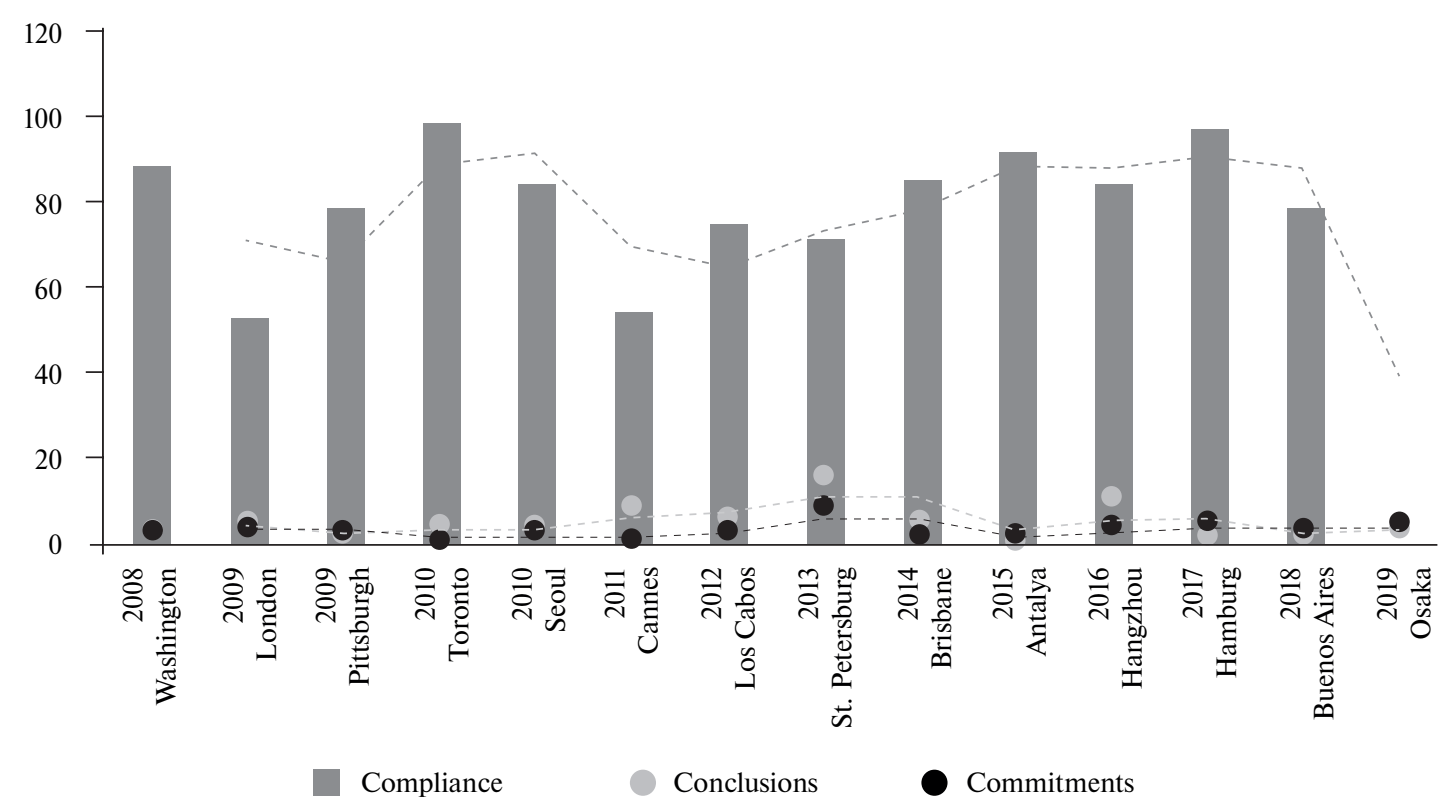

Fig. 4. G20 Compliance, Conclusions and Commitments on Tax (2008-18)

Source: [G20 Research Group, 2021. Data on file with author and available upon request].

Adopting a country-by-country focus further clarifies performance within the G20 club. As shown below (Fig. 6), the top five performers as of 2020 were the United Kingdom (91\%), the European Union (89\%), Germany (88\%), Japan (88\%) and Australia (86\%). Straddling the middle range of ten were France (86\%), Canada (81\%), South Africa (79\%), Argentina (76\%), India (76\%), Italy (76\%), China (74\%), Korea (74\%), Mexico (74\%) and Russia (74\%). The five poorest performers in the G20 club were the United States (74\%), Brazil (72\%), Indonesia (62\%), Turkey (60\%) and Saudi Arabia (59\%).

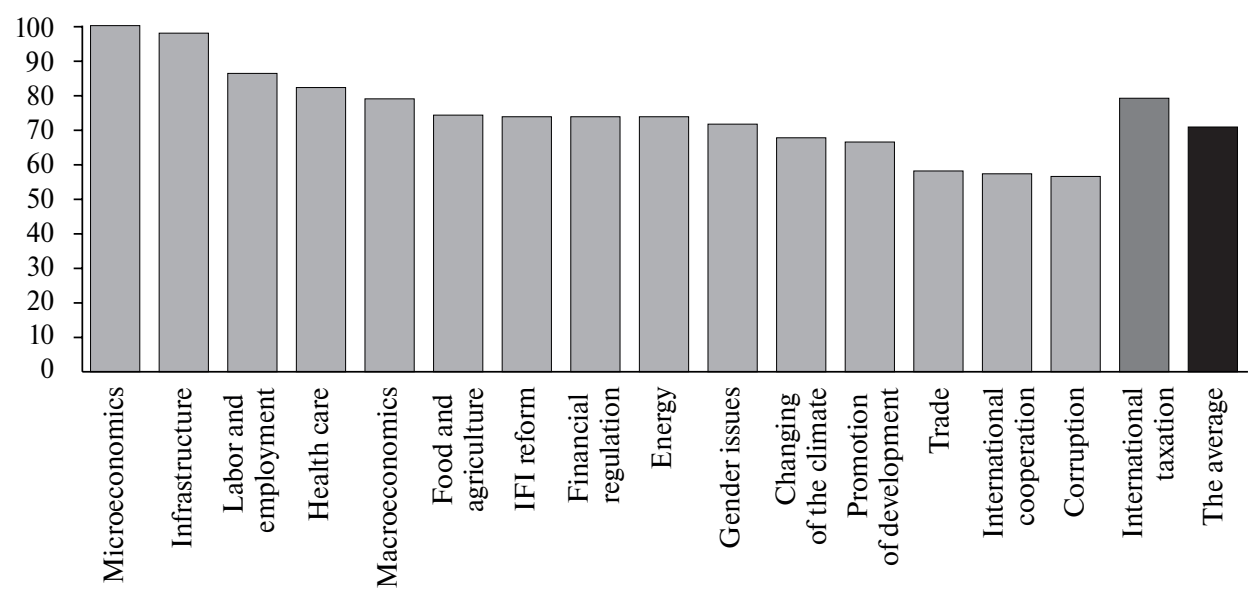

Fig. 5. G20 Performance by Issue Area (2020)

Source: [G20 Research Group, 2021. Data on hand with author and available upon request]. 


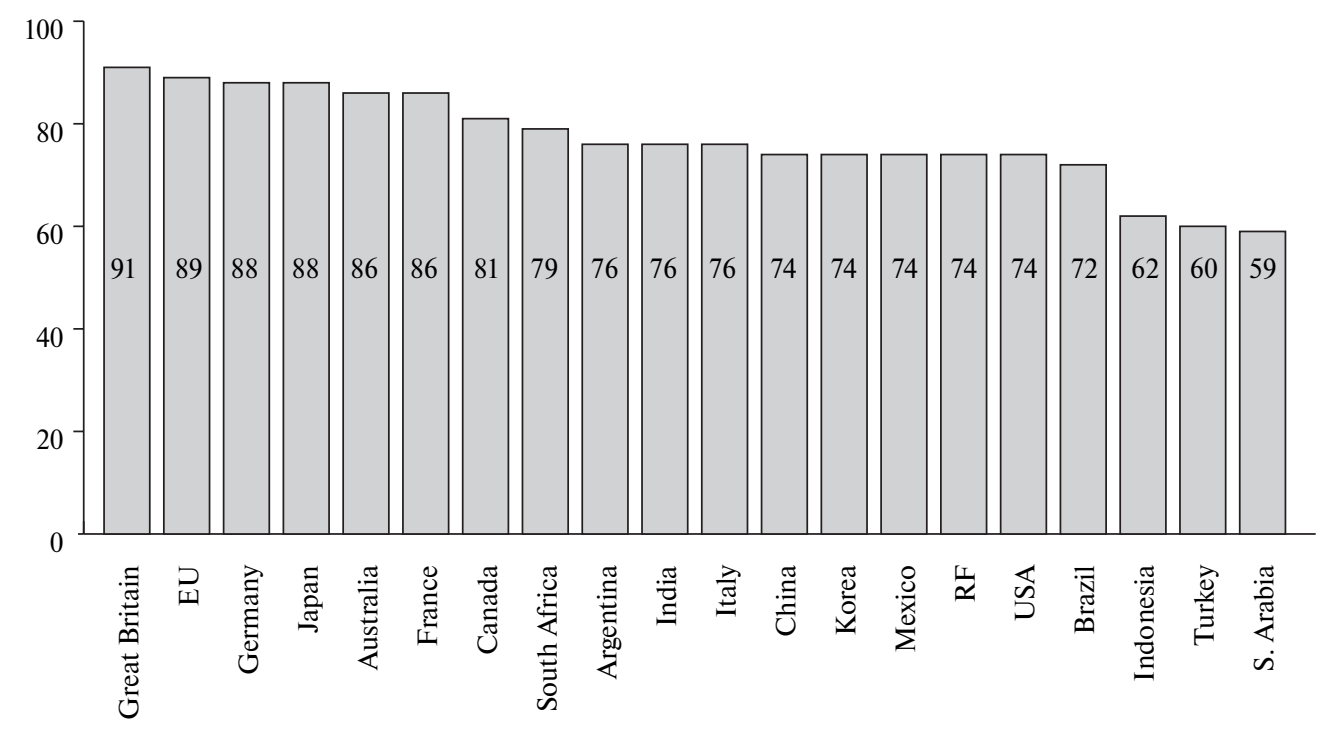

Fig. 6. G20 Member Performance on International Taxation (2020)

Source: [G20 Research Group, 2021. Data on hand with author and available upon request].

\section{Causes of G20 Compliance}

Among the many possible causes of this compliance, the most policy-relevant ones are the low-cost and often-used accountability measures under the leaders' direct control. They begin with the summit-specific causes of compliance, which includes an analysis of the relative weight of international taxation compared to other issue areas and compliance outcomes. Here, there was a negative relationship between the proportion of summit conclusions dedicated to tax and positive compliance at -0.44 that is significant at $1.35 \%$. There is also a modest negative relationship between the proportion of commitments dedicated to tax and positive compliance at -0.15 , although at $6.17 \%$ it is not considered significant. One reason may be the limited number - only 14 - of summits under consideration. Nonetheless, the "fewer for focus" is the message about how many tax conclusions and commitments summits should make to increase compliance.

The second set of accountability measures are the "catalysts" that leaders embedded in the text of the commitments, presumably to increase compliance with them (see Appendix A). There are 21 catalysts overall considered in the G20 Research Group methodology; however, only 17 catalysts were present in at least one of the commitments and considered in regression analyses. Multiple regression analyses were used to estimate the independent impact of each of these 17 key catalysts on compliance with the 31 commitments assessed. Two catalysts did so in a significant way. First, a highly binding verb that forcefully expressed the leaders' desire, such as taking action against non-cooperative jurisdictions, lowered compliance by $15 \%$. Second, reference to an international organization other than the core one of the OECD reduced compliance by $35 \%$, suggesting that the OECD is an institutional cause of compliance with commitments in the G20 club.

Thus, G20 members comply with their summit tax commitments at a high average level of $79 \%$. They register higher compliance with commitments from summits that produce fewer conclusions and commitments on tax and with commitments that have low binding verbs and 
that do not refer to international organizations other than the OECD, including those responsible for trade and tax. This suggests that this push from the top by G20 leaders is productive, but not sufficiently strong to produce the needed very high levels to implement action at the national level, as governments mobilize their executive, legislative and judicial branches to do the detailed work of enforcement. It also suggests that leaders' efforts to link their tax commitments to other international organizations, including those at the core of the international investment and trade regime, have not yet overcome the contradictions the latter may contain with the new BEPS-based international tax regime to make the latter fully work.

\section{A Dynamic Model of International Tax Governance}

To identify the prospects for, and pathway toward, a more effective new international tax regime in the digital age, a richer, more dynamic model is required. Building on the work of P. Dietsch and T. Rixen [2016, p. 333], a previous contribution to this journal proposed a General Model of the Global Fiscal Governance Process (hereinafter the General Model) that conceives of tax governance in stages ex ante and ex post [Motala, 2019, p. 62]. As shown below (Fig. 7), the model depicts fiscal policy and tax governance as a temporal process including several phases: diplomacy and agenda-setting, negotiation and standard setting, implementation, monitoring, and enforcement. The first two stages, diplomacy and agenda-setting and negotiation and standard setting, from $t_{0}$ to $t_{1}$, occur ex ante. The last three stages, implementation, monitoring, and enforcement, occur in the period from $t_{1}$ to $t_{2}$ and are considered to be ex post. The parsimonious model does not capture global policy feedback loops, such as the impact of enforcement on corporate special interests and ultimately on diplomacy and agenda-setting due to political lobbying, which may add to our causal understanding.

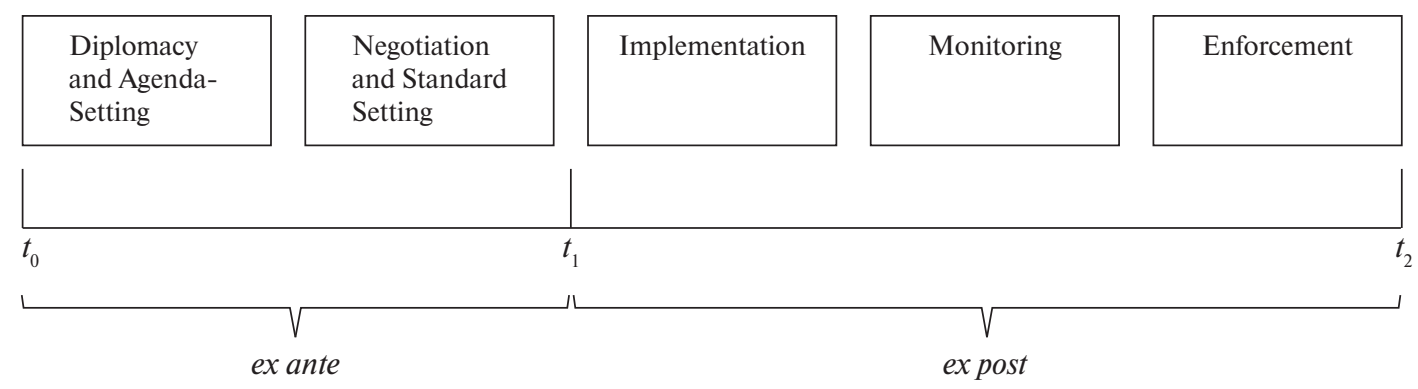

Fig. 7. General Model of Global Fiscal Governance Process

Source: Motala [2019] based on P. Dietsch and T. Rixen [2016].

Given historically high G20 compliance with tax commitments ex post at $79 \%$ overall, what drives diplomacy, agenda-setting, negotiation, and standard setting ex ante? Realist theory and the Model of System Hub Governance proposed by J. Kirton offer the best analytical guides to explain why international tax reform first emerged from 2008 to 2015, faltered under Donald Trump and then accelerated under President Biden with the pivot in the American approach to the global digital minimum tax [Kirton, 2013, pp. 27-54, 2021; Motala 2019].

Realism offers the concept of hegemonic stability to describe the leadership of a predominant power acting as necessary to maintain its privileged position in international relations by creating favourable institutional arrangements [Kirton, 2013, p. 28; Simmons, 2001]. Given the 
United States' dual role as a net loser in the global tax competition under the traditional regime, as illustrated by its declining share of global corporate tax receipts (Fig. 3), and as a declining economic hegemon, structural realism suggests that it had faced powerful incentives after the global financial crisis in 2008 to spearhead the international cooperation that culminated in BEPS 1.0. Poor progress in addressing the tax challenges of digitalization, specifically, then induced the United States Congress under the Trump administration to take unilateral action to impose minimum taxes for U.S. multinationals and threaten retaliation against non-cooperative jurisdictions and allies in Europe. This American pivot to unilateralism from 2016-20 shows that the Trump administration used a new calculus of its self-interest to reorient its foreign tax policy, as the American share of relative capabilities, although in secular decline, permitted it to act unilaterally on the global stage with little consequence for its national interests, especially as Trump benefited from newly strong U.S. economic growth.

The Biden administration then adopted a hybrid approach, combining the invitation to pursue a multilateral agreement on a minimum rate of corporate taxation with explicit threats for non-cooperation. This was due in part to the change in the partisan affiliation of national leadership from the Republican Party to the Democratic Party that forced a pivot back to the agenda of President Barack Obama, for whom Joe Biden had served as vice-president from 2009. It was also driven by a self-interested desire to increase U.S. corporate tax revenues as a proportion of GDP to keep up with America's international competitors in an increasingly digital age, now fuelled by the arrival of the COVID-19 pandemic and the ensuing lockdowns in early 2020. The economic impact of corporate tax base arbitrage stood out in President Biden's statements on his international tax agenda, in Treasury Secretary Janet Yellen's remarks to her diplomatic counterparts, and finally in statements made by U.S. Treasury Department official Kimberly Clausing to U.S. Congress in early 2021.

Thus, in all three phases of the institutional development of the international tax regime under G20 and OECD auspices since 2008, the United States acted as system-leading power concerned with redistributing untaxed profits from foreign tax havens to its Treasury to finance the restoration of its relative international position. In the first and third phases under the presidencies of Barack Obama (2009-17) and Joseph Biden (2021-present), facing the reality of America's diminishing share of global tax receipts and the prospect of relative decline, the U.S. emphasized a multilateral approach to reform the architecture of global tax and redistribute financial flows to its Treasury. As shown below (Fig. 8), in 2016 over half of U.S. multinational products were booked in Ireland, Bermuda (and the Caribbean), Switzerland, the Netherlands and Singapore, underscoring a rational case for policy action. However, in the second phase during the administration of President Donald J. Trump, in the context of a relative economic rise, the U.S. emphasized unilateralism with no multilateral constraints on the business activities of its leading technology giants. Therefore, at its core, shifts in American economic capabilities spanning these three phases, combined with China's economic acceleration despite the COVID-19 pandemic, motivated its actions on the international stage, serving as a driver of international tax cooperation and institutional evolution.

Yet, while realism provides the systemic structural context that "shapes and shoves" the behaviour of its state units, it is incomplete. As Kirton [2013] explained, "the causal links connecting relative capabilities to international institutional creation, operation, outcomes, and impact are seldom straightforward" [p. 28]. Structural realism is most salient during the initial diplomacy and agenda-setting and the negotiation and standard setting phases in the General Model above. Moreover, as Kirton pointed out, these theories "cannot cope well with their vulnerabilities as well as capabilities, with the interconnections among them, with the importance of horizontality as well as verticality in the international system, with the equal importance of those formerly relegated in a fast-moving globalized age" [pp. 29-30]. And, as a theory 
designed to explain balance of power behaviour, it does not capture the distinctive features of diplomacy and negotiation in the central forum of the G20, as a unique plurilateral summit institution (PSI) [p. 29].

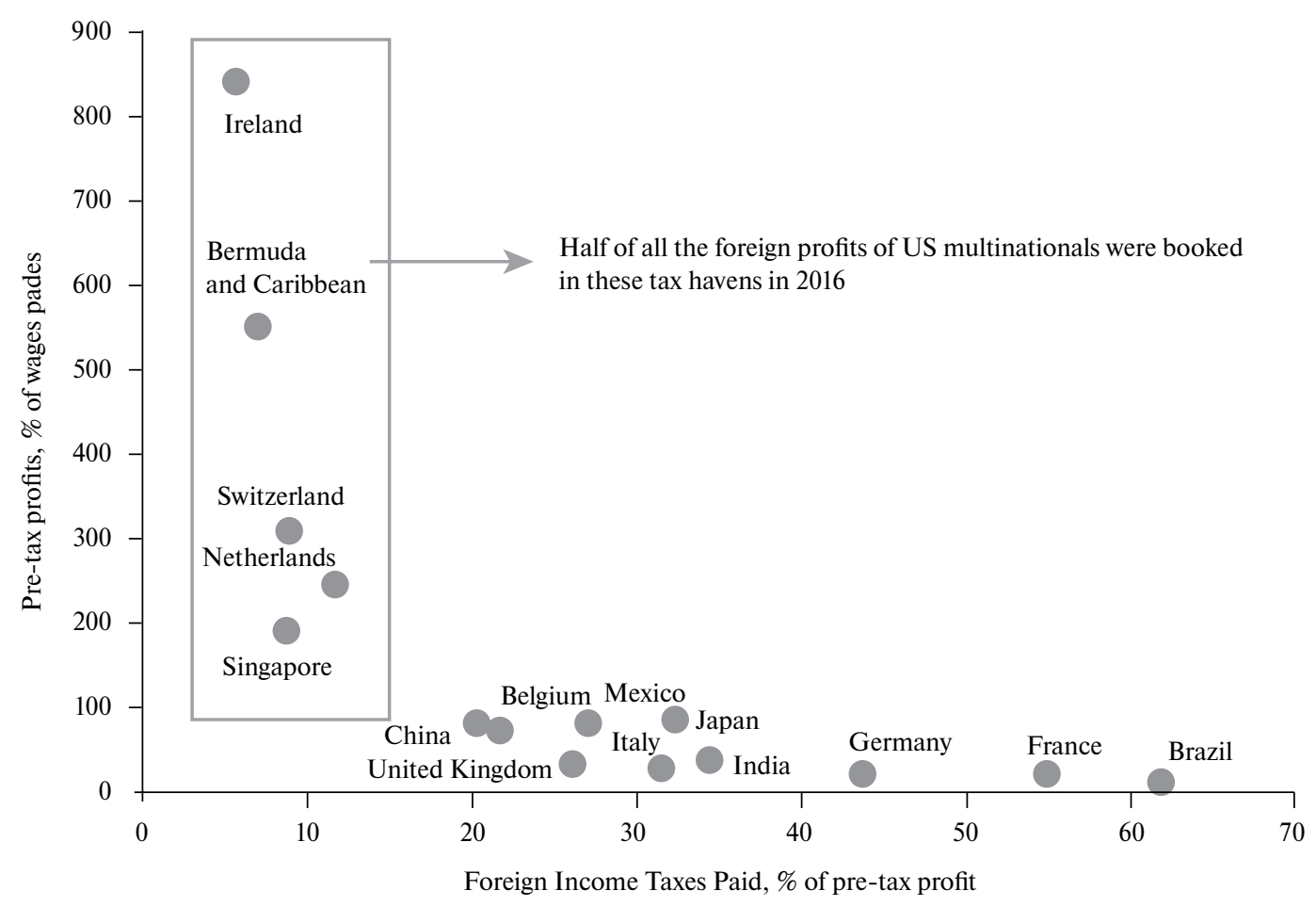

Fig. 8. Where Majority-Owned Affiliates of U.S. Multinationals Booked Their Profits (2016)

Source: This chart is used and reproduced with the permission of Professor Gabriel Zucman.

Note. Data sourced from https://gabriel-zucman.eu/exorbitant/

\section{The Enhanced Model of Systemic Hub Governance}

The Enhanced Model of Systemic Hub Governance [Kirton, 2013, 2021] (hereinafter the Kirton Model) supplements structural realism with three core concepts. First, it conceives of the contemporary international order as a complex adaptive system in "a world with no stable equilibrium, few constants... [and] linear causal relationships, path-dependent processes, multiple feedback loops, sudden and step-level jumps to new states, and a changing structure as a result" [Kirton, 2013, p. 33]. Complex adaptive systems are vulnerable to frequent shocks that stimulate an awareness of our "shared vulnerabilities... [that] triggers a common and collective loss-aversion instinct," creating a new demand for global governance in response [Ibid.].

Second, the G20 is a club, which typically emerges in response to global collective action problems; clubs are "are voluntary and exclusive, with non-members excluded from the benefits of membership," and to which "the benefits of belonging must outweigh the costs" [Kirton, 2013, p. 33]. The formation of the G20 represents a realist attempt to outsource the costs of U.S. hegemony to its economic allies [p. 34]. Clubs like the G20 are especially responsive to the shocks emerging from the complex global system as they meet annually at the leader and 
ministerial levels and "realize that if they do not all 'hang together' they will each hang alone" [pp. 34-5].

Third, the model construes of international affairs as networked, as the "world is no longer composed of formal hierarchies, but of spider web-like networks that confer benefits on the basis of connectivity rather than inclusion" [Kirton, 2013, p. 35]. Thus, in contrast with the structural realist ontology of international affairs that considers only national units, at one level, and international structure, at the other, the Kirton Model better accounts for the interconnectedness and interdependence of contemporary politics.

The Kirton Model evaluates performance along six key dimensions. The first is domestic political management, using the prestige that comes with participation in the club to improve popular standing and legitimacy by going abroad to promote their foreign policies [Kirton, 2013, p. 36, 2021, p. 7]. The second is deliberation that occurs privately and internally within the G20 [Kirton, 2013, p. 37]. The third is ideational direction setting by affirming "shared principles and norms, with principles defined from classic regime theory as statements of fact, causation, and rectitude and norms defined as more specific statements of prescription ('thou shall'), prohibitions ('thou shall not'), or permission ('thou may')" [Ibid.]. The fourth is decision-making, which refers to "the provision of credible, clear, collective commitments with sufficient precision, obligation, and delegation to serve as a reference point, a source of moral suasion, or a deterrent threat for outside actors who respond to G20 commitments in the intended way, even in the absence of further implementing action by G20 governments" [p. 38]. These four dimensions cover the General Model's first two, ex ante stages - diplomacy agenda-setting and negotiation standard setting. The final two dimensions cover the three, ex post stages - implementation, monitoring, and evaluation. The fifth dimension is delivery, which involves member governments' compliance with their leaders' and ministers' commitments [p. 39]. The sixth is the institutional development of global governance, involving "the creation, continuation, and evolution of the G20 as an international institution and ... of those to which it relates" [Ibid.].

The Kirton Model identifies six causes of high performance on these dimensions. The first is shocks that activate leaders' awareness about their shared vulnerability and thus prompt collective action [Kirton, 2013, p. 42]. Over the past decade, such shocks created by investigative journalism on tax avoidance and academic studies have played catalytic roles at key stages of BEPS 1.0 and BEPS 2.0. The second cause is multilateral organization failure, as the inflexible, inadequate or absent formal legal organizations from the Bretton Woods-UN galaxy created since 1944 respond poorly to these shocks, inducing PSIs such as the G20 to try to fill the resulting global governance gap [p. 43]. Shocks from the traditional international tax regime, based on over 3,500 double tax treaties (DTAs), had no dedicated multilateral organization to respond, leaving the plurilateral, analytical, consensus-oriented OECD and the new G20 leaders' summit to fill the gap. The third, core realist, cause is the globally pre-dominant, internally equalizing capabilities of G20 members, which back the globally effective governance they provide, induce them to work collectively, require all or most to agree, and allow almost any member to lead. G20 members possess approximately $85 \%$ of global GDP, so they thus have sufficient collective resources to undertake effective tax reform and to allow not just the U.S. but also other powerful members, such as France and the UK, to take or threaten unilateral action to secure more relative tax gains or spur multilateral regime reform [p. 44].

The fourth cause is converging domestic characteristics, which make it easier for members to agree on an agenda, principles, a focal point and a common win set for commitments, in ways that require less adjustment of national policies and less domestic change to comply with and implement the commitments they collectively make. All G20 members were subject to the increasing digitalization of their economies and consequent diminution of their tax revenues, 
especially after the COVID-19 lockdowns hit and simultaneously increased the need for new tax revenues to contain soaring fiscal deficits. From 2008 to 2021, the OECD members of the G20 had differing levels of corporate tax, especially after Trump took the already low U.S. level even lower. This increasing divergence from the OECD-G20 norm reduced the G20's performance and led to U.S. unilateralism. Convergence also facilitates the legibility of each member to the others and thus the sharing of information and the recognition and adoption of best practices among them. G20 performance on BEPS 1.0 and the Inclusive Framework could be attributed to the convergence of domestic characteristics within the G20 and emulation and mutual adjustment by OECD and non-OECD members in the Inclusive Framework, facilitated by the OECD [Kirton, 2013, p. 45].

The fifth cause is members' domestic political cohesion, which allows them to adjust to forge G20 agreements knowing that they will be supported and implemented at home. Its components are the leaders' summit experience, professional expertise and personal commitment to a cause, their control of their executive and legislative branches, regulatory agencies and subnational governments, their public support, and the timing of their next election [Kirton, 2013, p. 46]. Donald Trump's departure from the move to meet the December 2020 deadline came when he encountered difficulties in his presidential re-election campaign.

The sixth cause is the position of the G20 as the leaders' cherished club at the hub of an extensive and expanding network of global summit governance. Of particular importance is the position of the host as the core of the hub, the move of the G20 from an instrumentally to an interpersonally cherished club, and its spokes into other summit institutions of global relevance and reach. Also relevant is the array of guest leaders who attend a summit and the PSIs to which they belong. A key measure is the extent to which the PSIs in the G20 network govern on the specific subject, in this case international tax, that the G20 summit governs. Whether they do so before or after the G20 summit gives an initial estimate of the flow of influence from or to the G20, as a measure of whether the G20 summit leads or follows the other PSIs. In the case of tax, the membership of a G20 summit participant in the ministerial-level OECD is expected to increase the latter's compliance with its G20 tax commitments, given the G20's close partnership with the OECD in international tax reform.

\section{Addressing the Enforcement Gap}

The systemic hub model of governance, or the Kirton Model, is extremely useful to the extent that it provides an explanation for the first four stages of tax governance; however, it fails to address the outcomes of G20-OECD-guided global tax reform, namely the enforcement dimension, as the final stage and ultimate concern of the current reform effort [Motala, 2019, p. 68]. Legal enforcement occurs domestically, when the administration and enforcement of tax law and regulation for resident persons and legal entities is done by treasuries or their bureaucratic equivalent. When a taxpayer takes issue with a tax assessment, the finding can be challenged in a court of law. In contrast, and specific to transnational corporations with foreign subsidiaries, taxpayers seeking to challenge a corporate tax assessment on the grounds that it constitutes double taxation of the same underlying economic activity (meaning that another country has already taxed the profits) have recourse to a process at the international level involving national tax administrations in the executive branch. Here, the taxpayer initiates an intergovernmental MAP, in which two state bureaucracies negotiate a resolution. Tax-related issues can also be pursued by private companies against states at the international level in the ISDS arbitration regime. Here, an investor claims that an investment protected by a treaty has been expropriated on the grounds of changes to national tax laws, or that they have been treated 
unfairly and inequitably. Thus, the main concern of the next section is the state of affairs of global tax dispute resolution through the MAP and ISDS.

\section{Global Tax Dispute Resolution and the Mutual Agreement Procedure}

Structural weaknesses in the international tax regime flow from its archaic nature, being nearly a century old, and the fact that it fosters global tax competition among states, inducing countries to competitively underbid each other in a "race to the bottom" to attract a higher absolute number of tax receipts. To assess whether a global minimum tax will be implemented, and whether it will be effective, requires addressing the enforcement gap in the analysis. Assuming the reformed regime is agreed in its envisaged substantive form, legal reasoning and economic insights guide a conjecture about its legal outcomes. This conjecture starts with the current state of enforcement under the BEPS Inclusive Framework by examining the relevant legal instruments, statistics on global tax disputes, and prospective conflicts of norms between global tax and cognate areas of international economic law. This analysis demonstrates that, despite attempts to reform enforcement through the MLI, the current state of tax dispute resolution under ISDS poses a threat to the implementation of the digital minimum tax and the BEPS 2.0 agenda more broadly.

International tax consists of a complex, networked architecture of DTAs that address the risk of double or multiple taxation. Double taxation occurs when two states each apply a tax to one economic activity, therefore taxing the corporate taxpayer twice, creating inefficiencies and economic distortions. The rules in tax treaties are intended to address how countries distribute the global tax base at the highest level of generality. Yet these rules are subject to abuse, resulting in corporate tax arbitrage. Domestic tax statutes impose tax liabilities on all persons with socioeconomic ties to a country, as well as non-residents who earn an active income, such as income from employment, or passive income, such as capital gains, in relation to economic activities within the jurisdiction. DTAs grant relief to taxpayers for tax liabilities owed under domestic tax law when there is more than one competing sovereign claim to levy taxation on an economic activity [Ismer, Piotrowski, 2016, p. 350].

As shown below (Fig. 8), the legal structure of DTAs is unique. DTAs are bilateral international agreements signed by two state parties and ratified into domestic law in each country. When a dispute is raised by the taxpaying corporation, it is brought to the national tax administration in the respective country, which then engages in intergovernmental MAPs with counterparts in the other jurisdiction through an intergovernmental diplomatic process. Under DTAs following the OECD Model agreement, national tax administrations apply internal law to national taxpayers. With respect to international tax matters, corporations are indirect beneficiaries of the DTA, meaning they cannot make a tax appeal through normal legal channels, such as a court, and have no formal legal standing in the MAP process.

Contrary to its objective to limit double taxation, the complex DTA network also provides opportunities for sophisticated corporate tax planning to reduce the overall global tax burden of a given transnational corporation, defined as conducting business in two or more countries via foreign subsidiaries. This practice involves the manipulation of transfer pricing, intra-group loans, and treaty shopping. Transfer pricing rules govern transactions between related entities in a TNC group and exist to ensure that transactions occur at a fair market value as between nominally arm's length entities, given that many companies exploit these transactions to shift profits to lower tax jurisdictions. Intra-group loans refer to loan arrangements between related entities that allow the group to deduct interest from a related-party loan from profits in a certain jurisdiction to shift the profit to a lower tax jurisdiction. Treaty shopping refers to corporations 
using favourable tax treaty provisions in DTAs to reduce their liabilities. Transnational corporations are uniquely capable of these kinds of tax practices because, unlike domestic corporate entities, they engage in economic activities that transcend national borders.

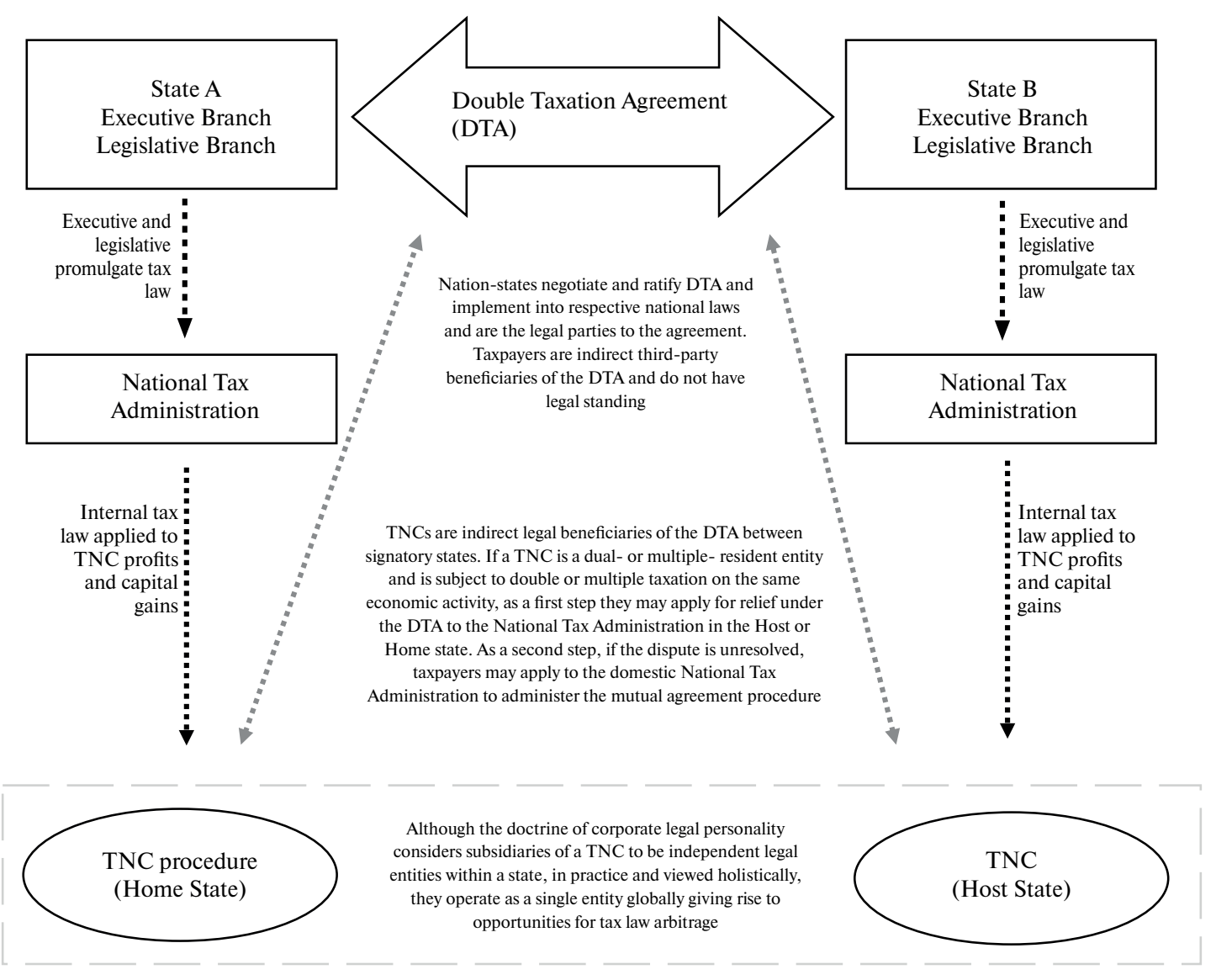

Fig. 9. The Legal Structure of DTAs

Source: Diagram expands on basic framework articulated in Castillo-Murciego and Lopez-Laborda [2019, p. 17].

Given the historic lack of political will to pursue a multilateral tax convention, the practical difficulties of reconciling different national tax systems, and the economic disincentives posed by global tax competition, the entry into force of the MLI pursuant to Action 15 of the BEPS agenda on 1 July 2018 was seen as "a breakthrough" by certain scholars of international taxation [Bacia, Toporowski, 2018, p. 387]. The historic agreement came from negotiations among over 100 jurisdictions, which ended in November 2016, and the MLI currently covers 94 jurisdictions representing $95 \%$ of global GDP. However, scholars note that the MLI "is not a fully-fledged multilateral tax convention covering all the areas that are usually covered in bilateral tax treaties" [Avi-Yonah, Xu, 2018, p. 158]. Rather, the convention is a "consensual treaty override designed to apply the Base Erosion and Profit Shifting (BEPS) (Inclusive Framework) simultaneously to all the tax treaties where the countries involved agree" [Ibid.]. The MLI is an "umbrella agreement that legally modifies the relevant provisions of bilateral agreements on the avoidance of double taxation ... at the level of legal construction under international tax 
law" [Ibid.]. It is an instrument that will "transpose results from the OECD/G20 Base Erosion and Profit Shifting Project (BEPS) into more than 2,000 tax treaties worldwide" [p. 155]. Coverage of the 3,800 bilateral investment treaties (BITs) is therefore not comprehensive, but is substantial.

In addition to preventing double taxation and double non-taxation, tax treaties exist to facilitate trade and investment by providing investors with legal certainty, that is, "the idea that the law must be sufficiently clear to provide those subject to legal norms with the means to regulate their own conduct and to protect against the arbitrary exercise of public power" [Verburg, 2019, p. 426]. DTAs and other investment treaties are thus intended to assure capital exporters that the same economic activity will be taxed fairly. For international investment, treaties provide taxpayers certainty that overlapping sovereign claims will be subject to certain procedural norms. Tax treaties thus standardize definitions and the jurisdiction of contracting states, promote the exchange of information that assists with enforcement, limit or prevent taxpayers from exploiting loopholes through "treaty shopping," and materially impact the rate of taxation of TNCs [Blonigen, Davies, 2000, p. 6].

The MLI's dispute settlement regime contained in the MAP does not go far enough to address substantive deficiencies in the legal regime. Article 16, which is Part V of the multilateral convention on Improving Dispute Resolution describes the MAP. The provision enables taxpayers "to present grievances under the [Covered Tax Agreements [CTA]] ... and express intent for the tax jurisdictions to resolve issues under the CTA in agreement with each other," and it envisages intergovernmental negotiations rather than a judicial procedure per se [Morley, 2019, p. 239].

There are three types of MAP cases under the MLI, being the interpretive, legislative and specific varieties [Ismer, Piotrowski, 2016, p. 352]. The specific MAP case is the most relevant to the discussion because it permits "taxpayers to request intergovernmental dispute resolution by way of a negotiation between competent authorities of the contracting states," providing them with a "remedy additional to and independent from any domestic treaties" [Ibid.]. It is concerned with specific disputes brought by a taxpayer who "considers that he is or will be taxed in a manner contrary to the treaty" and is the only kind of case that can be subject to arbitration [Ibid.]. Rather than a judicial proceeding, the MAP originates in the norms of diplomatic protection since the contracting parties are states themselves and the procedures allow "states to reach a common understanding on their contractual obligations under international law and thus serve a coordination function" [p. 353].

To an extent, the MAP is nothing new as a method of intergovernmental coordination, as it has been a feature of tax dispute resolution since it was first proposed under the auspices of the League of Nations and was codified by the OECD in 1968. In addition to the MLI, the MAP procedure is codified in Article 25 of the OECD Model Tax Convention on Income and Capital, which serves as the template for approximately $75 \%$ of DTAs in existence [Markham, 2019, p. 5]. According to OECD statistics as depicted below (Fig. 10), at the end of 2018, there were approximately 9,564 MAP cases pending. The majority of these cases involve disputes over TNC transfer pricing, which "refers to the pricing of intercompany transactions based on the arm's length principle, i.e., what independent enterprises dealing in the open markets would have been charged for comparable transactions," with corresponding "income adjustments [that] may be made by revenue authorities to bring them into line with this amount" [p. 6]. According to the European Commission, in 2017 there were approximately 900 double taxation disputes in the European Union overall, with an estimated value of 10.5 billion euros [EC, 2017].

Although the MAP has been a feature of international tax dispute resolution between contracting states, the regime is rightfully subject to criticism. For one, H. Mooij pointed out 
that an increasing number of cases are unresolved [2019, p. 203]. J. Duffy and T. Bailey noted that the taxpayer is in an "invidious position in the current international tax environment" due to a "tax dispute resolution framework which has failed to provide the efficiency and certainty required by international business" [2017]. They added that the MAP framework is not "fit for purpose" and is undermined by three factors: a lack of compulsion on parties to engage in the process; the "absence of an obligation on the parties to resolve the dispute"; and finally "the lack of a time limit on negotiations" between contracting states [Ibid.]. The empirical evidence also suggests that the MAP procedure faces an incredible backlog of pending cases that are unevenly distributed geographically. As shown in OECD 2018 data, the United States alone had 1,007 pending cases in 2018, while India had 841 and Canada had 147. By contrast, in the same year Saudi Arabia had only three, Argentina had 13 and Australia had 31. According to the OECD, in 2019 the average wait time for cases involving transfer pricing was 30.5 months, while the wait for other cases was 22 months, underscoring its procedural inefficiencies [OECD, 2019]. As further shown below in 2019 data (Fig. 10), disputes may last anywhere from approximately two to 68.59 months on average depending on the jurisdiction in which they are raised.

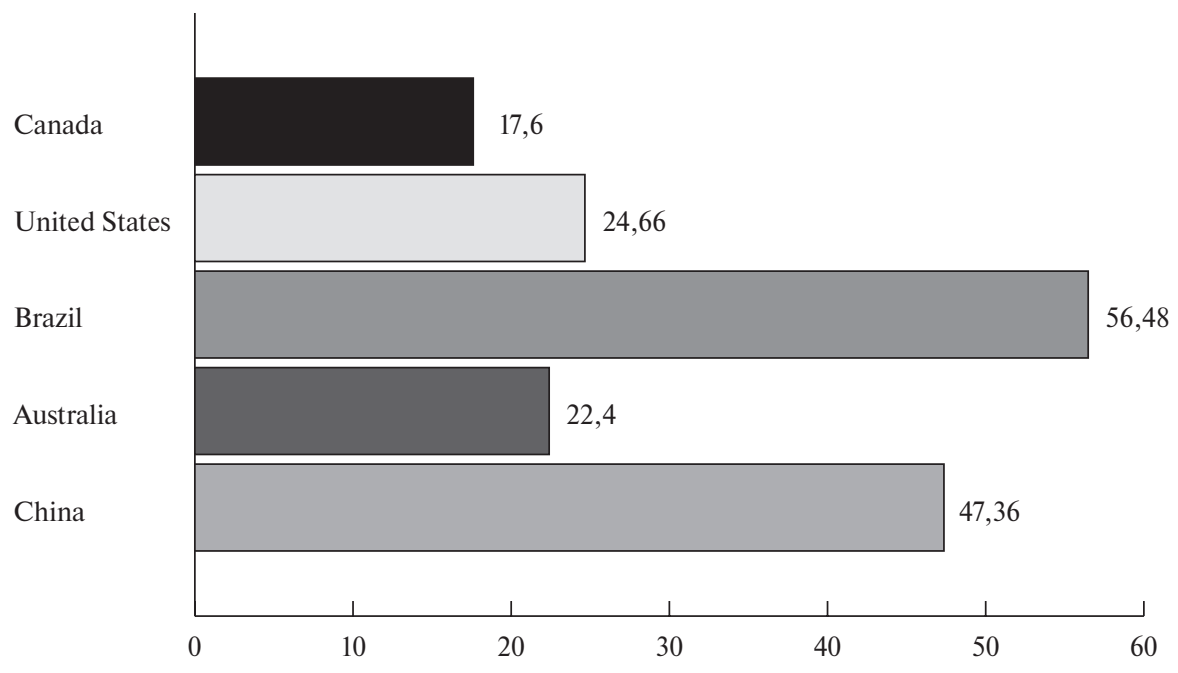

Fig. 10. Mutual Agreement Procedure Average Time for Closure in Months, 2019

Source: [Organisation for Economic Co-operation and Development, 2021].

As part of the BEPS Action Plan, in 2013 the OECD pledged to enhance the MAP framework with binding and mandatory arbitration, which would form an "integral part of the procedure that would enhance its effectiveness" [Markham, 2018, p. 4]. Arbitration can be defined as a "quasi-judicial, binding, and private instrument of dispute settlement based on a contract between the involved parties" [Majdanska, Turcan, 2018, p. 4]. In Arbitration in Taxation (1981), G. Lindendcroma and N. Mattsson "made the ground-breaking proposal to complement the individual case MAPs by tax treaty arbitration for cases where states have failed to settle within a certain timespan" [Ismer, Piotrowski, 2016, p. 254]. The MLI contains an optional mandatory binding arbitration provision in Part VI, which encompasses Articles 18 through 26 of the instrument [Markham, 2019, p. 21]. Article 19 permits arbitration when an aggrieved taxpayer "bring[s] an action under Article 16 of the MLI [the MAP], thus claiming that one or both of 
the jurisdictions is taxing in violation of the applicable [DTA]" covered by the MLI [Morley, 2019 , p. 240]. In particular, arbitration is available "where the tax authorities of the two contracting jurisdictions are unable to resolve the controversy within two years of one of several specific dates" if the party bringing the suit desires, with the arbitration to be implemented on the basis of mutual agreement [Ibid.]. There must be a pre-dispute agreement to arbitration, which means "an irrevocable agreement to arbitrate was concluded before rather than after the dispute arose," meaning "arbitration may proceed even if one side later changes its mind and would prefer to have the dispute resolved in its own national courts" [Markham, 2019, p. 3].

Nevertheless, as J. Chaisse argued, MAPs "do not guarantee an investor can bring a case to international arbitration because arbitration is only supplementary to MAPs, and investors have to go through a lengthy process to have a case heard by an arbitration tribunal" [2016a, p. 167]. In addition, Article 19 of the MLI prescribes several cases where arbitration may not occur [Morley, 2019, pp. 240-1], and Articles 18 through 26 contain detailed rules governing the arbitration [Bacia, Toporowski, 2018, p. 393]. Parties to an arbitration under the MLI may elect between two scenarios: first, they may elect for a final offer, "in which each of the authorities in the double-taxation agreements proposes to resolve the matter, leaving the final choice to the arbitrators"; second, they may elect for an independent opinion, "in which arbitrators issue a decision based on their own independent judgment through analysis of evidence in the case" [Ibid.]. Both contracting parties must agree on the same scenario to be employed or the arbitration will not proceed. Finally, Article 21 of the MLI provides that the arbitration proceedings must be kept confidential.

The optional, consensual and supplemental nature of the arbitration provision in the MLI reflects a lack of consensus and political will amongst OECD members. Indeed, following the publication of the BEPS Action Plan, "the OECD swiftly realized that there was no consensus amongst countries on moving towards a universal mandatory binding MAP arbitration" [Markham, 2019, p. 4]. The majority of countries that were opposed, such as India, registered concern with binding arbitration on the grounds of sovereignty concerns and the need to preserve sovereignty over taxation matters [Mooij, 2019, p. 205]. Moreover, in certain cases a contracting state's constitution or national laws may prohibit tax administrations from delegating a dispute to a foreign jurisdiction [Ibid.]. Due to a lack of consensus, the MLI's provision on MAP arbitration is optional and applies only with the express consent of contracting parties [Markham, 2019, p. 21] Since signatories to the MLI were not compelled to adopt mandatory arbitration under Action 15, as of 2019, only 29 of the 94 signatories to the MLI opted into the mandatory arbitration clause.

Even if a digital minimum corporate tax is fully implemented, the underlying weaknesses of enforcement provisions of the MLI threaten to undermine current efforts to eliminate corporate tax avoidance and arbitrage. As shown in statistics on pending MAP caseloads, there is a significant backlog of unresolved cases distributed unevenly by geography, suggesting that the intergovernmental approach to dispute resolution is inefficient and there are significant bureaucratic hurdles limiting its effectiveness. Furthermore, analysis of changes to the legal instrument in the form of the optional arbitration mechanism in the MLI shows that it does little to address core issues with investor standing in the process. Accordingly, the lack of progress with respect to tax dispute resolution creates powerful incentives for transnational corporations to litigate their tax disputes in alternative judicial fora in an effort to reduce their global tax burden. Therefore, if the G20 and the world's leading powers wish to holistically address the tax challenges of digitalization, base erosion and tax arbitrage, reform of tax dispute resolution is warranted in addition to a minimum digital tax. 


\section{Tax Jurisprudence in International Investment Law}

Aside from the intrinsic weakness of tax dispute resolution in the MLI, there are extrinsic threats to the prospective effectiveness of a global minimum tax in the realm of international investment law and the ISDS regime. Analysis of a growing body of tax jurisprudence litigated in the cognate regime of international investment law suggests the principle of tax sovereignty in global taxation is on a collision course with the investor protection principle in ISDS. In the 22 taxation disputes occurring within the ISDS regime considered in this article $(n=22)$, the sum total of damages awarded to investors was a staggering $\$ 41,223,010,020.14 .^{2}$ Notably, these tax-related cases involved transnational corporations that directly challenged a state's tax laws through BITs rather than through the MAP. As Chaisse explained, "the multiplication of tax disputes before investment tribunals represents a significant change in the landscape of international investments" [2016a, p. 164]. Determining if a tax dispute is subject to ISDS, one has to evaluate whether a given investment subject to a national tax regime constitutes a 'foreign investment' within the meaning of international law," which would in turn permit a corporate taxpayer to challenge tax administration in an alternative forum to the MAP [p. 156]. Put another way, if taxation is included in the scope of a relevant treaty, foreign investors may "challenge their host states for changes in the relevant domestic legislation that could harm their investments," and thus "a clash could emerge between the implementation of BEPS and the application of BITs that include taxation within their scope" [Chaisse, Marisi, 2016, p. 162].

Today, international investment law is comprised of a network of 3,300 treaties, most of which are bilateral, although the ISDS regime encompasses multilateral treaties as well. Examples include free trade agreements (FTAs) such as the United States-Maxico-Canada Agreement (USMCA) and the EU-Canada Comprehensive Economic and Trade Agreement (CETA), regional agreements such as the Trans-Pacific Partnership (TPP), and sectoral agreements such as the Energy Charter Treaty (ECT) [Korzun, 2017, p. 363]. Figure 11 below depicts the proliferation of BITs from 1957 to 2019. In addition to its legal foundation in BITs, regional investment agreements, and FTAs, the ISDS regime is supported by a series of international institutions and procedural arbitration rules and can be considered a form of global governance

\footnotetext{
${ }^{2}$ Note that the following cases and dispositions were analyzed in the course of research for this article: Perenco Ecuador Limited v The Republic of Ecuador, ICSID Case No. ARB/08/6, TCW Group, Inc. and Dominican Energy Holdings, L.P. v. The Dominican Republic; Venezuela Holdings, B.V., et al [case formerly known as Mobil Corporation]; Venezuela Holdings, B.V., et al. v. Bolivarian Republic of Venezuela, ICSID Case No. ARB/07/27. Hulley Enterprises Limited [Cyprus] v. The Russian Federation, UNCITRAL, PCA Case No. AA 226; Yukos Universal Limited [Isle of Man] v. The Russian Federation, UNCITRAL, PCA Case No. AA 227; Veteran Petroleum Limited [Cyprus] v. The Russian Federation, UNCITRAL, PCA Case No. AA 228; The Rompetrol Group N.V.v. Romania, ICSID Case No. ARB/06/3”, Burlington Resources, Inc. v. Republic of Ecuador [ICSID Case No. ARB/08/5]; Quasar de Valores SICAV, S.A., Orgor de Valores SICAV S.A., GBI 9000 SICAV S.A. and ALOS 34 S.L. v. The Russian Federation [SCC Case No. 24/2007]; Jan Oostergetel and Theodora Laurentius v. The Slovak Republic, El Paso Energy International Company v. Argentine Republic [ICSID Case No. ARB/03/15]", Señor Tza Yap Shum v. The Republic of Peru, ICSID Case No. ARB/07/6; Sergei Paushok, CJSC Golden East Company and CJSCVostokneftegaz Company v. The Government of Mongolia; RosInvestCo UK Ltd. v. The Russian Federation [SCC Case No. 079/2005]; EDF [Services] Limited v. Republic of Romania [ICSID Case No. ARB/05/13]; Corn Products International, Inc. v. United Mexican States [ICSID Case No. ARB[AF]/04/1]; Limited Liability Company Amto v. Ukraine [SCC Case No. 080/2005]; Tokios Tokelés v. Ukraine [ICSID Case No. ARB/02/18]; Enron Creditors Recovery Corporation [formerly Enron Corporation] and Ponderosa Assets, L.P. v. Argentine Republic [ICSID Case No. ARB/01/3]; EnCana Corporation v. Republic of Ecuador [LCIA Case No. UN3481]; Marvin Roy Feldman Karpa v. United Mexican States [ICSID Case No. ARB[AF]/99/1]; Link-Trading Joint Stock Company v. Department for Customs Control of the Republic of Moldova; Antoine Goetz and others v. Republic of Burundi [I] [ICSID Case No. ARB/95/3]. All cases are available at UNCTAD [n. d.].
} 
[Koivusalo, 2019, p. 112-4]. The World Bank established the International Centre for Settlement of Investment Disputes (ICSID) in 1966 following the Convention on the Settlement of Investment Disputes between States and Nationals of Other States signed in 1965, which has since been ratified by 154 states.

The ICSID is a key forum for the settlement of investment disputes between host states and investors [Islam, 2018, p. 2]. Many investment agreements may rely on the United Nations Commission on International Trade Law (UNCITRAL) rules to govern the disposition of their claim, while others may rely on the rules of commercial arbitration promulgated by the London Court of International Arbitration (LCIA) or the International Chamber of Commerce (ICC) [Ibid.]. Although not all claims brought under the ISDS regime are publicly disclosed, the available evidence collected by the United Nations Conference on Trade and Investment (UNCTAD) in Figure 12 below shows that at 36\%, the plurality of claims are decided in favour of the state, $30 \%$ are decided in favour of the investor and $21 \%$ of cases are settled, with the remainder either discontinued, settled or decided in favour of neither party. Compared to the MAP, the disposition of ISDS cases suggests that binding arbitration proceedings may be more efficient than intergovernmental negotiation over tax jurisdiction.

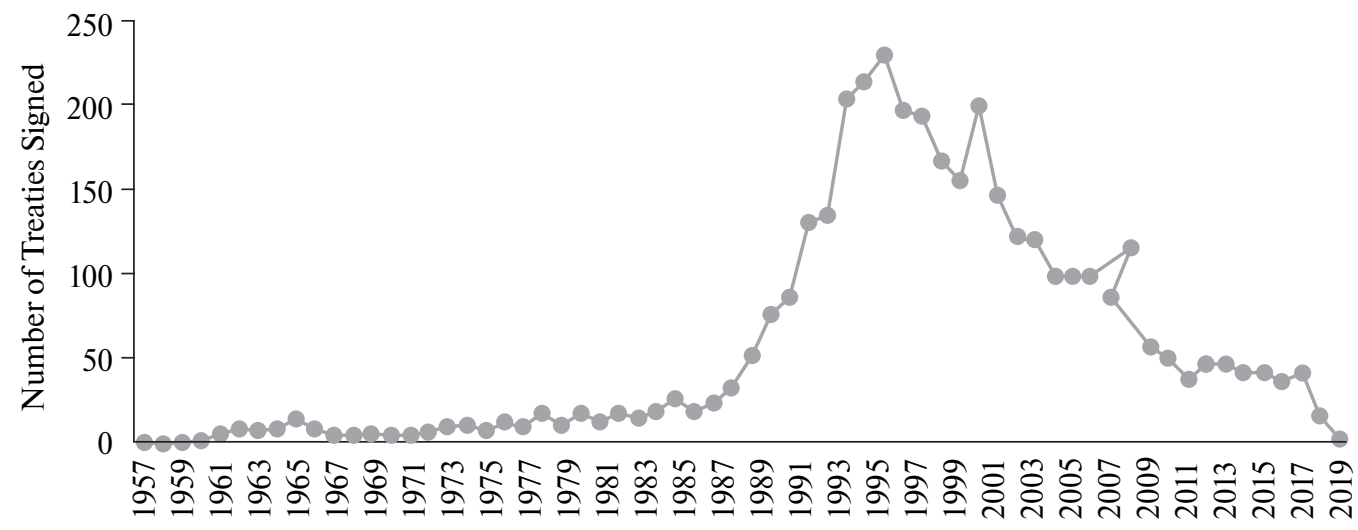

Fig. 11. Number of Bilateral Investment Treaties (BITs) Signed (1957-2020)

Source: [UNCTAD, n. d.]

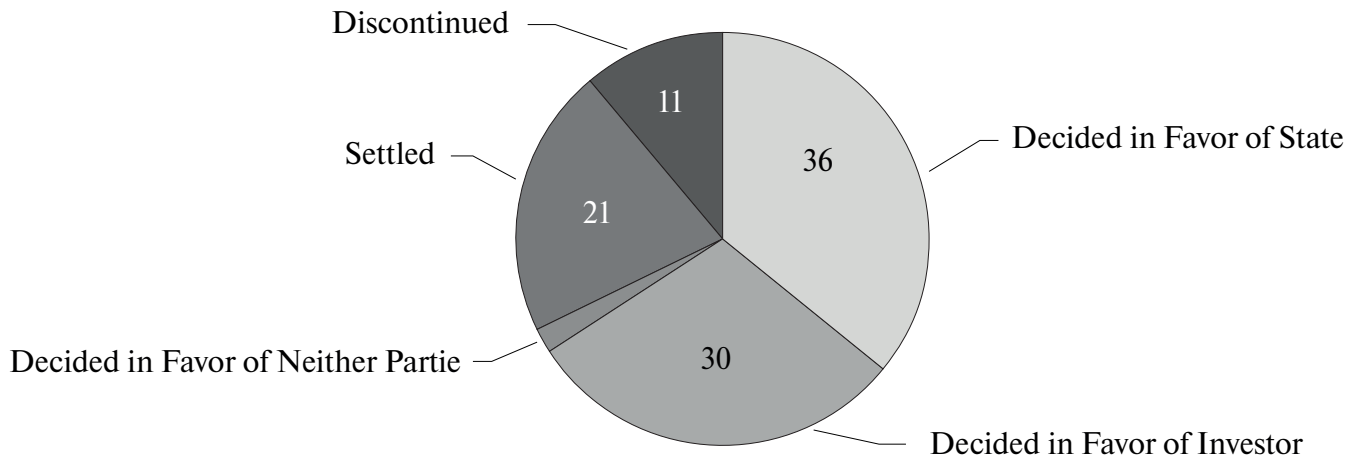

Fig. 12. Disposition of Public ISDS Cases

Source: [UNCTAD, n. d.] 
The key legal objective of ISDS is to promote foreign investor protection and to provide investors with certainty that the value of their investment will not be diminished as a result of government intervention. ISDS strives to ensure a stable and predictable environment by ensuring there is access to arbitration if a state breaches its obligations under a BIT or other investment agreement [Chaisse, 2016a, p. 152]. The four principal investor protection obligations imposed on the state in ISDS relate to non-discrimination, fair and equitable treatment (FET), protection from direct and indirect expropriation, and full protection and security (FPS). ISDS is ultimately concerned with the protection of the international investor's private property rights, and it does so by signalling the state's credible commitment to binding dispute resolution in an international convention that provides remedies where investor rights have been breached.

ISDS and tax governance are engaged in a conflict of norms that have practical implications for both legal regimes and international business. As Chaisse argued, "tax treaty and international investment law prima facie appear to be two different worlds and two different legal regimes," yet "they largely overlap, as evidenced by the rising number of cases brought before investment tribunals related to tax disputes" [2016b, p. III]. To understand why, consider how tax law thus interacts with investment: the prospect of double taxation can impact the choice of an investment host, transfer pricing rules can increase costs of compliance, tax may create a climate of uncertainty, and exit taxes levied on profit distort the global allocation of capital and labour [Chaisse, Marisi, 2017]. Thus, to attract foreign direct investment (FDI), states will provide foreign investors with tax relief and other incentives to attract capital [Owens, Zhan, 2018 , p. 1]. Since host states often provide preferential tax regimes to attract international investment, and corporations can challenge subsequent changes to those preferential regimes, and thus bring taxation measures with within the remit of ISDS [Haufler, Mardan, Schidler, 2018, p. 25].

The conflict of norms between ISDS and tax sovereignty reveals a core tension between the investor protection objective, on the one hand, and the state's right to regulate in the public interest, on the other. Investor protection calls for legal certainty and imposes obligations on states not to discriminate, expropriate or violate other broad standards without incurring a liability. In the domestic political context, regulation can be understood broadly as "any act of the legislature, public administration, or courts that is an exercise of the regulatory or police power of the state" [Korzun, 2017, p. 373]. Internationally, "the expression of the right to regulate [is] that a state may enter into international investment treaties and, in doing so, undertake investor protection obligations" [Ibid.]. A core issue is thus whether ISDS conflicts with the legitimate welfare objectives of domestic tax sovereignty among other regulatory areas, and if so, whether it risks a "regulatory chill" effect that harms the public interest. To critically evaluate this tension and its implication for both regimes, this article considers tax dispute jurisprudence under the ISDS regime in the context of indirect expropriation claims and the FET standard, which are universally worded clauses in the BIT network and other investment treaties. Under both standards, arbitrators are tasked with balancing the narrow objective of investor protection with the domestic objective of public policy and regulation concerned with promoting the general welfare [Hepburn, 2017, p. 6].

\section{Expropriation}

Of the 22 cases analyzed for this study, 20 cases, or $91 \%$ overall, contained investor claims of direct and indirect government expropriation of the underlying value of their investment, and it is the most often claimed provision overall. In the disposition of the cases, overall tribunals found a total of $41 \%$ in favour of expropriation claims, being nine cases total. There are two main types of expropriation claimed in ISDS: direct and indirect expropriation. Whereas di- 
rect expropriation contemplates the seizure and nationalization of an investor's assets, indirect expropriation refers to "government actions that have a substantial adverse impact on a firm without nationalizing a firm outright," which, given the broad language used to draft the clause, "is difficult to define precisely ... in practice ... in particular since the law does not prevent a government from rightful regulation" [Eckhard, 2018, p. 1173]. Indeed, examining the jurisprudential record, scholars note the "debate has shifted to the application of indirect expropriation to regulatory purposes aimed at protecting the environment, health, and other welfare interests of society" since government policy and actions can affect a compensable "taking" from investors [Yannaca-Small, 2010, p. 446].

The prohibition on indirect expropriation exists "to provide a guaranteed, absolute minimum standard of protection regardless of the standards that might be contained in domestic law" [Hepburn, 2017, p. 61]. As extant case law suggests, once there is a finding of expropriation, other conditions - such as the public purpose animating the impugned measure, whether the action was non-discriminatory and whether it followed the due process of domestic law are largely irrelevant to the juridical analysis [Ibid.] As a consequence, J. Hepburn [Ibid., p. 7] noted that "many states and their citizens already feel slighted by the perceived disregard of their interests and circumstances." In this vein, V. Korzun added that "the reputation of investorstate dispute settlement (ISDS) has suffered a heavy blow in recent years" [2017, p. 357]. Given the prominence of expropriation claims in the cases examined and their relatively high success rate of $41 \%$, there is clear evidence of a growth of tax-related cases in ISDS, as well as emergent legal avenues for transnational corporations to effectively challenge states' sovereign tax prerogative.

\section{Fair and Equitable Treatment Standard}

Of the 22 cases analyzed for the study, 15 cases, or $68 \%$ overall, contained investor claims of a violation of the FET standard, and it is the second most often claimed provision overall in the data set. In the disposition of the cases, overall tribunals found a total of $23 \%$ in favour of FET claims, five cases in total, rendering it the second highest claim accepted by arbitral tribunals. FET clauses are found in the majority of BITs and other investment agreements, and provide that states must treat investors in a fair and equitable manner according to a minimum standard of treatment in customary international law.

FET clauses are worded very generally and are typically vague, leading to a range of interpretations by arbitral tribunals and a lack of precedent. The broad and open-ended construction of FET has led it to become one of "the most contentious issues in the field" in jurisprudence, aided by the fact that "the FET standard serves as a core [if not the core] protection instrument foreign investors," and the language of the FET standard promulgated in the majority are so similar that scholars argue "there is an overarching and singular concept of FET" [Islam, 2018, p. 20]. From the investor perspective, the FET clause is intended to protect legitimate expectations when investing in host countries. From the state perspective, the FET standard, like expropriation clauses, may conflict with the state's right to regulate as a function of the expression of its police powers.

\section{Conflict of Norms Between ISDS and Tax Governance}

Given the investment protections afforded by the ISDS network of treaties and the coordinated tax law changes produced by BEPS, scholars think it is possible there could be a tidal wave of investment arbitration concerning domestic tax law and policy. Other scholars forecast a "per- 
fect storm" of international tax disputes pursued under ISDS because of "untested international tax rules, inconsistent implementation and interpretation in different jurisdictions, increased information sharing, and a drive to raise revenues" [Duffy, Bailey, 2017]. From the investor perspective, there is a lack of certainty in the MLI concerning cross-border disputes and the prospect of unresolved double taxation cases [Owens, Zhan, 2018, p. 4]. What is more, there has been a "dramatic surge" of investment disputes in the area of tax, which is "contributing to the formation of a jurisprudence that is elucidating the meaning of key provisions and contributing to the emergence of global economic regulation for tax matters" [Chaisse, 2016a, p. 149].

Although the vast majority of BITs can be used to challenge national tax law and regulation, not all BITs exercise jurisdiction over questions of national fiscal policy. While there are many BITs that include tax within their investment protection jurisdiction, many model and actual BITs contain exclusions, exceptions, vetoes and other clauses that address the conflict of norms with tax governance. For example, Article 2103.1 of the NAFTA provides that "except as set out in this Article, nothing in this agreement shall apply to tax measures" [Chaisse, 2016a, p. 162]. The 2007 French Model BIT stipulates that "the provisions of this article [national treatment and most favoured nation] do not apply to tax matters" [p. 163]. Similarly, the 2007 German Model Treaty specifies that "the treatment granted under this Article shall not relate to advantages with either Contracting States' accords to investors of third States by virtue of a double taxation agreement or other agreement regarding matters of taxation" [Ibid., p. 163]. Article 21 of the 2012 United States Model BIT provides that nothing "shall impose obligations to tax measures" generally, although it provides that expropriation claims may be brought only after the claimant has referred the matter to competent tax authorities under tax governance.

Even if a global digital minimum tax is agreed and implemented, the conflict of norms between tax and investment law highlights a fundamental flaw in the contemporary approach to tax governance reform. Due to the complexity of the BIT network and the lack of double taxation carve-outs, the global minimum tax and other BEPS-related reforms are vulnerable to litigation on the grounds of the investor protection principle contained in BITs, and therefore tax base erosion and corporate tax arbitrage. Given the practical implications of this conflict of norms as borne out in the tax jurisprudence surveyed in this study, in addition to strengthening tax dispute resolution under the MLI, U.S. leadership and global policymakers ought to reform the BIT network to address double taxation loopholes.

\section{Conclusion}

This article has argued that G20 states' compliance with a prospective global minimum corporate tax rate of $21 \%$ will be high based on their past performance and the distribution of relative capabilities in the international system, but it will not go far enough. Recent reforms to the global tax dispute resolution mechanisms of the MLI failed to address the substantive deficiencies in the current MAP, which is the cornerstone of state-to-state tax dispute resolution. In particular, the MAP remains deficient given the lack of binding arbitration, the lack of formal taxpayer standing in the legal process, the bureaucratic inefficiency of the intergovernmental procedure itself, evidence of backlogged cases, and most critically, the ability for multinational corporations to challenge the implementation of BEPS and a digital tax given loopholes in the related regime of international investment law.

Therefore, to advance a new paradigm of tax governance, policymakers should consider more than adding mandatory arbitration to the current MAP. There is in fact a growing number of tax cases in which private corporations challenge the tax laws of sovereign states, which indicates a conflict of norms between the international tax and investment regimes that has practi- 
cal implications for the implementation of a global minimum tax and other BEPS objectives. Put simply, U.S. leaders and global policymakers must address the conflict of norms between tax sovereignty and investor protection and the interaction of tax law with the ISDS regime if BEPS 2.0 is to work.

\section{References}

Ali F. (2020). Charts: How the Coronavirus Is Changing Ecommerce. Digital Commerce 260, August 25, 2020. Available at: https://www.digitalcommerce360.com/2020/08/25/ecommerce-during-coronavirus-pandemicin-charts/.

Avi-Yonah R.S., Xu H. (2018). A Global Treaty Override? The New OECD Multilateral Tax Instrument and Its Limits. Michigan Journal of International Law, vol. 39, no 2, pp. 155-216. Available at: https://repository.law. umich.edu/mjil/vol39/iss2/2 (accessed 2 June 2021).

Bacia B., Toporowski P. (2018). OECD Multilateral Instrument: The New Era in International Tax Law. Journal of Advanced Research in Law and Economics, vol. 2, no 32, pp. 386-95. Available at: https://doi.org/10.14505// jarle.v9\%202(32).03

Blonigen B.A., Davies R.B. (2000). The Effects of Bilateral Tax Treaties on US FDI Activity. NBER Working Paper Series No 7929, National Bureau of Economic Research. Available at: https://doi.org/10.3386/w7929

Chaisse J. (2016a). Investor-State Arbitration in International Tax Dispute Resolution: A Cut Above Dedicated Tax Dispute Resolution? Virginia Law Review, vol. 41, no 2, pp. 149-222. Available at: https://www.researchgate.net/publication/305047024_Investor-State_Arbitration_in_International_Tax_Dispute_Resolution-_A_Cut_above_Dedicated_Tax_Dispute_Resolution (accessed 3 June 2021).

Chaisse J. (2016b). International Investment Law and Taxation: From Coexistence to Cooperation. E15 Task Force on Investment Policy Think Piece, World Economic Forum. Available at: https://www.rieti.go.jp/en/ events/16071201/pdf/10_am2-5_chaisse.pdf (accessed 3 June 2021).

Chaisse J., Marisi F. (2017). Another Conflict of Norms: How BEPS and International Taxation Relate to Investment Treaties. Investment Treaty News, 2 June. International Institute for Sustainable Development. Available at: https://www.iisd.org/itn/2017/06/12/another-conflict-norms-how-beps-international-taxationrelateinvestment-treaties-julien-chaisse-flavia-marisi/

Dietsch P., Rixen T. (2016). Global Tax Governance: What's Wrong and How to Fix It. Colchester: ECPR Press.

Duffy J., Bailey T. (2017). Tax Disputes Post-BEPS: A Perfect Storm. International Tax Review, 17 March. Available at: https://www.internationaltaxreview.com/article/b1f7n6czfxfljf/tax-disputes-post-beps-a-perfect-storm (accessed 3 June 2021).

European Commission (EC) (2017). Resolution of Tax Disputes in the European Union. Available at: https:// ec.europa.eu/taxation_customs/business/company-tax/resolution-double-taxation-disputes_en_en (accesed 3 June 2021).

Giles C., Harding R. (2020). Richest Nations Face \$17tn Government Debt Burden From Coronavirus. Financial Times, 24 May. Available at: https://www.ft.com/content/66164bbc-40c7-4d91-a318-a0b4dbe4193e (accessed 3 June 2021).

Haufler A., Mardan M., Schindler D. (2018). Double Tax Discrimination to Attract FDI and Fight Profit Shifting: The Role of CFC Rules. Journal of International Economics, vol. 114, pp. 25-43. Available at: https:// doi.org/10.1016/j.jinteco.2018.04.007.

Hepburn J. (2017). Domestic Law in International Investment Arbitration. Oxford University Press.

Islam R. (2018). The Fair and Equitable Treatment (FET) Standard in International Investment Arbitration. Singapore: Springer.

Ismer R, Piotrowski S. (2016). A BIT Too Much: Or How Best to Resolve Tax Treaty Disputes? Intertax, vol. 44, no 5, pp. 348-59. Available at: https://kluwerlawonline.com/journalarticle/Intertax/44.5/ TAXI2016028 (accessed 3 June 2021). 
Kerzner D.S., Chodikoff D.W. (2016). International Tax Evasion in the Global Information Age. Basingstoke: Palgrave MacMillan.

Kirton J. (2013). G20 Governance for a Globalized World. Surrey: Ashgate.

Koivusalo M. (2019). Rights, Regulation and Redistribution: The Global Politics of Investment Protection. Global Social Policy, vol. 19, no 1-2, pp. 105-20. Available at: https://doi.org/10.1177\%2F1468018119839745

Korzun V. (2017). The Right to Regulate in Investor-State Arbitrations: Slicing and Dicing Regulatory Carve Outs. Vanderbilt Journal of Transnational Law, vol. 50, no 2, pp. 355-414. Available at: https://law-journalsbooks.vlex.com/vid/the-right-to-regulate-683838617 (accessed 3 June 2021).

Lee D. (2020). Amazon Doubles Quarterly Profits Despite Covid-19 Costs. Financial Times, 30 July. Available at: https://www.ft.com/content/7a42b1d8-9ca7-4827-aaae-729fdb7637f5 (accessed 3 June 2021).

Majdanska A., Turcan L. (eds) (2018). OECD Arbitration in Tax Treaty Law. Vienna: Linde.

Markham M.A. (2019). Arbitration and Tax Treaty Disputes. Arbitration International, vol. 35, no 4, pp. 473504. Available at: https://doi.org/10.1093/arbint/aiz023.

Mooij H. (2019). Tax Treaty Arbitration. Arbitration International, vol. 35, no 2, pp. 195-219. Available at: https://doi.org/10.1093/arbint/aiy004

Morley J. (2019) Why the MLI Will Have Limited Direct Impact on Base Erosion and Profit Shifting. Northwestern Journal of International Law and Business, vol. 39, no 2, pp. 225-47. Available at: https://scholarlycommons.law.northwestern.edu/njilb/vol39/iss2/4 (accessed 3 June 2021).

Motala M. (2019). The G20-OECD Contribution to a New Global Tax Governance. International Organisations Research Journal, vol. 14, no 3, pp. 52-79. Available at: https://doi.org/10.17323/1996-7845-2019-02-03.

Organisation for Economic Co-operation and Development (OECD) (2015). Measuring and Monitoring BEPS: Action 11 Final Report. Available at: https://www.oecd.org/ctp/measuring-and-monitoring-beps-action-11-2015-final-report-9789264241343-en.htm (accessed 3 June 2021).

Organisation for Economic Co-operation and Development (OECD) (2019). Mutual Agreement Procedure Statistics for 2019. Available at: https://www.oecd.org/tax/dispute/mutual-agreement-procedure-statistics. htm (accessed 3 June 2021).

Owens J., Zhan J.X. (2018). Trade, Investment and Taxation: Policy Linkages. Transnational Corporations, vol. 25, no 2, pp. 1-8. Available at: https://doi.org/10.18356/861c6aa6-en

Reuters (2020). UK Treasury Seeks "Tax Raid" to Fill Gap Left by Pandemic, Reports Say. Globe \& Mail, 30 August. Available at: https://www.theglobeandmail.com/business/international-business/article-uk-treasuryseeks-tax-raid-to-fill-gap-left-by-pandemic-reports/ (accessed 3 June 2021).

Simmons B.A. (2001). The International Politics of Harmonization: The Case of Capital Markets Regulation. International Organization, vol. 55, no 3, pp. 589-620. Available at: https://doi.org/10.1162/00208180152507560.

Torslov T., Wier L., Zucman G. (2018). The Missing Profits of Nations. VOX CEPR Public Policy, 23 July. Available at: https://voxeu.org/article/missing-profits-nations (accessed 3 June 2021).

United Nations Conference on Trade and Development (UNCTAD) (n. d.). Investment Dispute Settlement Navigator. Investment Policy Hub. Available at: https://investmentpolicy.unctad.org/investment-dispute-settlement (accessed 3 June 2021).

Verburg C. (2019). Modernising the Energy Charter Treaty: An Opportunity to Enhance Legal Certainty in Investor-State Dispute Settlement. Journal of World Investment \& Trade, vol. 20, no 2-3, pp. 425-54. Available at: https://doi.org/10.1163/22119000-12340144

Yanaca-Small K. (ed.) (2010). Arbitration Under International Investment Agreements: A Guide to the Key Issues. Oxford University Press. 